\title{
Reform Of The Livestock Trade
}

\section{The organization of the Kansas City Livestock Exchange helped restore integrity to livestock trade in the area.}

By KC Olson

To portray the organization of the Kansas City Livestock Exchange as resulting from a benign consensus among the commission merchants would be inaccurate. Certainly, two platforms around which the exchange was organized enjoyed wide approval among potential members: livestock disease control and restoring integrity to the Kansas City trade.

There was, however, dispute over the issue of setting standard consignment rates. In order for all commission firms to compete effectively, the policy of offering commission rebates had to be abolished. Two competing factions emerged over this issue. The free-trade faction consisted of well-es tablished, large commission houses. the fledgling organization.
They wanted to reserve the right to offer commission rebates as they saw fit. The regulator faction, made up of relatively new, small commission houses, opposed the free-trade faction. They wanted uniform consignment rates set for all commission houses.

In spite of these philosophical differences, organization of the Kansas City Livestock Exchange went forward. Members of the regulator faction were at the forefront of organizing the exchange; however, they invited all commission firms to join and all eventually accepted. They also invited livestock traders, packers, and the Kansas City Stockyards Company to provide insight into the operation of

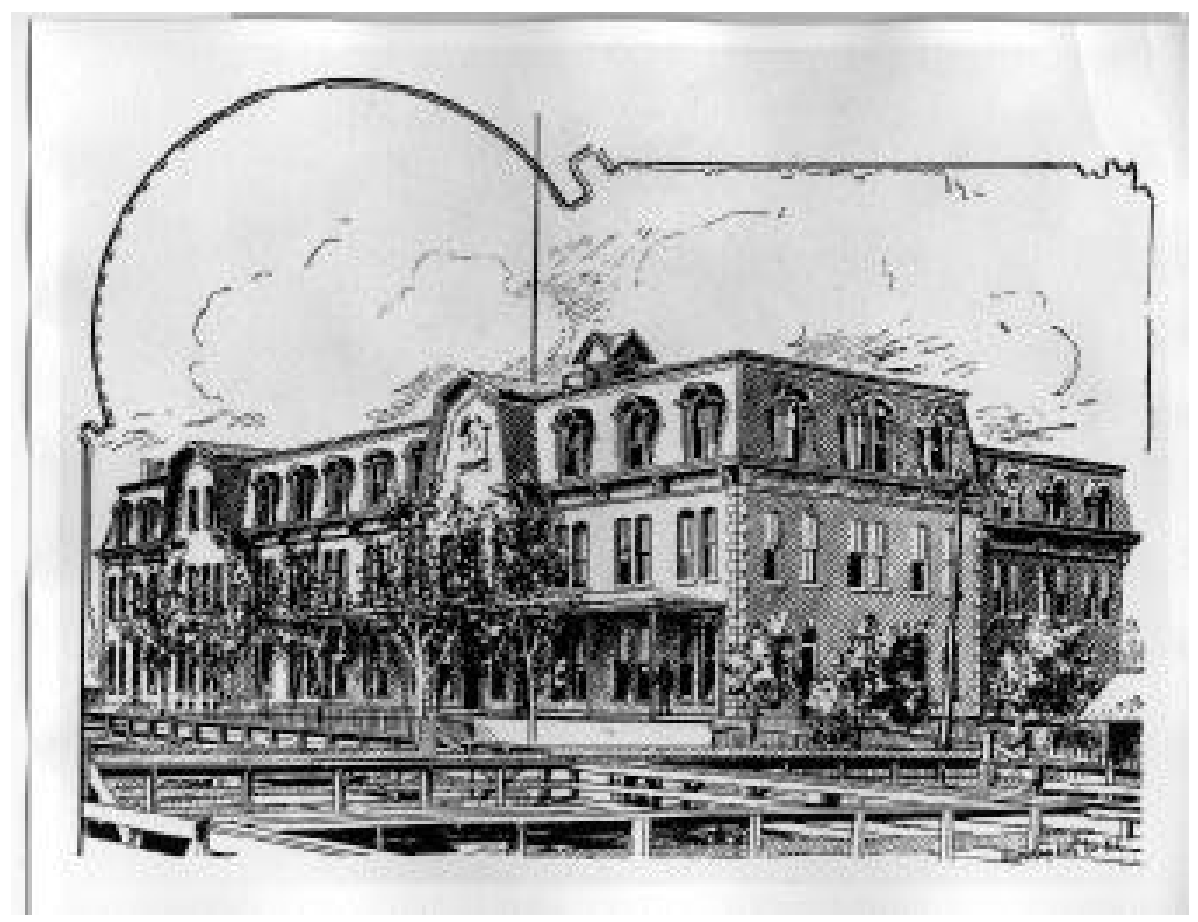

The Kansas City Livestock Exchange building, as it appeared in 1887. Provided by the Kansas State Historical Society - Topeka, Kansas. Reprinted with permission.
Historian O.J. Hazlett (1987) provides an excellent overview on the organization and operation of the Kansas City Livestock Exchange. The exchange was organized around a ninemember board of directors, a president, and four appointed committees that were tasked to accomplish specific goals of the exchange. Directors were elected for a 3-year term and the president for a 1-year term.

The Kansas City Stockyards Company and a consortium of local packers were allowed to appoint one representative each to the board of directors. Although the terms of service for these two positions were indefinite, the commission merchants always maintained control of the board. The board met a minimum of 12 times per year but could hold special sessions whenever necessary. Ten members of the Kansas City Livestock Exchange, by signing a petition, could force the directors to call a special meeting. Members also had the power of referendum over decisions made by the directors.

Initially, the board of directors appointed an executive committee, an arbitration committee, and an appeals committee. In 1899, they added an investigating and judiciary committee to prosecute rule-breakers within their own ranks. There were five members of the exchange on each committee, including one representative from the Kansas City Stockyards Company and one from the packer consortium.

A series of self-imposed taxes, fees, and fines were used to fund operations of the Kansas City Livestock Exchange. There were taxes levied upon each carload of livestock re- 


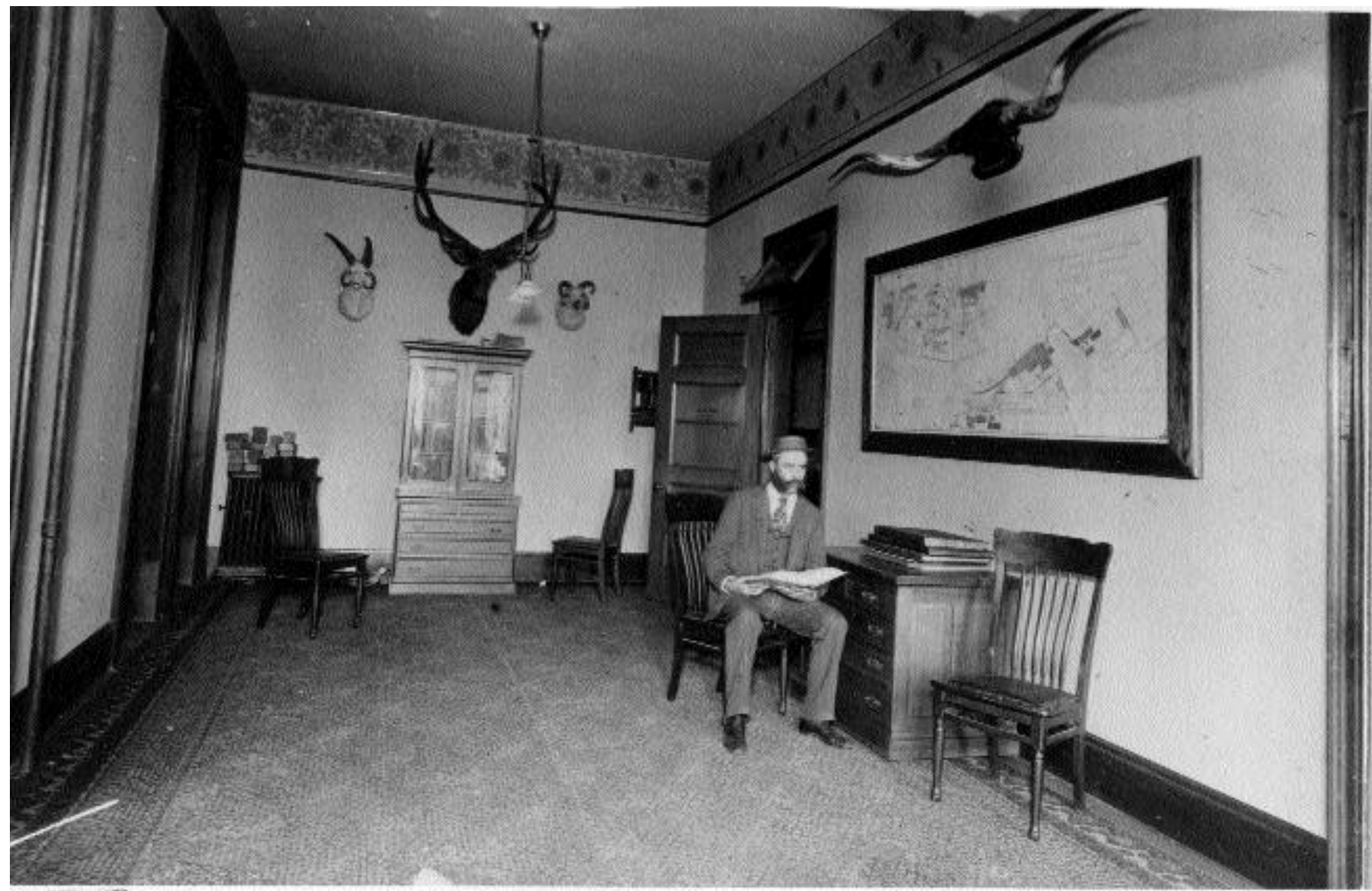

The general managers office in the Kansas City Livestock Exchange building, as it appeared in the late 19th century. Provided by the Kansas State Historical Society - Topeka, Kansas. Reprinted with permission.

ceived at the Kansas City yards, fees for membership and arbitration, and fines levied upon members for rule infractions. The exchange was relatively inexpensive to operate. In 1908, income to the exchange was $\$ 14,559.54$, while cash outlays totaled $\$ 12,028.54$. Sixty-three percent of this income was from rail car taxes, $4 \%$ from arbitration fees, $7 \%$ from membership dues, and $21 \%$ from fines levied against members.

The constitution of the Kansas City Livestock Exchange granted the board of directors the power to prosecute and discipline violators of the rules. The board of directors was empowered to fine, censure, suspend, or expel offending commission merchants; however, it could not discipline a member without itself convening a commercial trial. The accused were allowed to defend themselves but could not employ professional legal counsel. Refusal to appear before any committee or commercial court brought an automatic suspension from the exchange. Additionally, if a member sought injunction from any court of law against the exchange, the exchange considered their membership forfeited.

The rules of the exchange specifically forbade any member from taking commercial disputes into a court of law. Commission merchants were required to submit all commercial disputes to the arbitration committee of the exchange. Independent livestock traders, farmers, and ranchers could force a dispute into arbitration simply by notifying the board of directors. In the event that a customer was unsatisfied with the decision of the arbitration committee, the appeals committee would review the dispute. Decisions by the appeals committee were final and binding. Commission merchants who refused to pay an award ordered by either the arbitration or appeals committees guaranteed their expulsion from the exchange by the board of directors. The investigating and judiciary committee, by their charter, was supposed to prosecute rule violators aggressively. Even a rumor of impropriety was enough to precipitate an investigation. The committee was also responsible for presenting charges and evidence against accused exchange members during commercial trials.

\section{Reform Returned Prestige To Kansas City Yards}

Once the administrative and revenue gathering structures of the Kansas City Livestock Exchange had been determined, members set out to address the specific biological and ethical 
dilemmas that were facing the commission trade. To exercise control over the spread of livestock diseases, the executive committee hired public inspectors and placed one at each of the 12 scales located in the stockyards. The job of the inspector was to monitor all animals as they crossed the scales and to mark or quarantine any that were diseased, injured, or otherwise imperfect. The decision of an inspector could be appealed to a chief inspector in charge of adjudicating all disagreements. There was no appeal from the chief inspector's decision.

The inspectors hired by the exchange were not necessarily qualified to spot a diseased animal. Recognizing this, the U.S. congress passed legislation placing qualified veterinarians in all the major markets. These officials did not replace the exchange inspectors, but merely stationed themselves near the scales and watched for diseased animals while the exchange personnel monitored the remaining ones. The first government inspectors appeared at the Kansas City stockyards in 1894. The exchange initially opposed the presence of the government veterinarians on the grounds that they were redundant; however, that attitude changed over time. Soon the government veterinarians convinced the exchange members that their services were essential. In 1920, when the appropriations for government stockyard inspectors were drastically reduced, the exchange hired their own veterinarians to serve that function.

The public inspectors also provided the solution for the dockage swindle. The exchange board of directors immediately removed the packer-paid hog docker from the stockyards and replaced them with their own inspection personnel. Each inspector was paid by the exchange and favored neither the producer nor the packer. The fact that the decision of an inspector could be appealed was well received by livestock producers and traders in particular. The entire inspection system was surprisingly effective throughout the life of the exchange.
The exchange board of directors acted quickly to eliminate fraud from the Kansas City commission trade. All member firms of the exchange were required to provide written authorization empowering the board of directors to audit their account books and telegraph messages as needed. The threat of a surprise audit made it very difficult for the commission merchants to falsify sales accounts. As a result, livestock producers and traders had greater assurance of receiving all the money that was their due. Any merchant found guilty of fraud during a commercial trial was expelled from the exchange.

Equally important was the board's ability to examine all market-related telegraph traffic. Members of the exchange who telegraphed false market reports in order to stimulate livestock shipments during periods of low prices would invariably be caught. The board also limited market quotes by commission firms to only those sales that the firm itself had transacted.

The exchange reduced other opportunities for fraud by redefining the role of the commission house solicitor and regulating business hours. The exchange forbade commission firms to pay solicitors based on a percentage of consignment fees; moreover, they required solicitors to register with the secretary of the exchange by name and address. The exchange also required all solicitors to be employed on a full time basis; no longer could a solicitor also be a railroad livestock agent or a cattlemen's association representative. In imposing restrictions on the nature of the solicitor's position, opportunities for conflict of interest in livestock sales largely disappeared.

The exchange also limited the time the stockyards and the commission firms remained open to transact sales to daylight hours. This policy ensured that every seller would be able to market their livestock with maximum price competition among buyers. It also made the commission business more public; it became nearly impossible to carry out a misdeed in the stockyards without someone else witnessing it.

The Kansas City Livestock Exchange recognized early that livestock producers and traders had no security against crooked transactions or insolvency of the commission firms. To remedy the situation, the exchange forced commission firms to put up a bond to ensure that merchants returned all monies to customers who sold livestock on consignment. Few businesses thought in terms of a surety bond before the turn of the $20^{\text {th }}$ century but the Kansas City Livestock Exchange pioneered its use as early as 1893. The price of membership in the exchange could also be used as a form of surety bond. Any commission merchant caught defrauding a customer was expelled from the exchange; that merchant's membership was then sold and the proceeds were used to help reimburse the defrauded customer.

Despite these measures, fraud and insolvency continued to be a problem. In 1912, the exchange created a collection agency tasked to verify that all buyers had the necessary cash to complete their proposed transactions. Later, the exchange provided a blanket bond for all commission merchants. The exchange first used the blanket bond to reimburse customers who lost money as a result of the insolvency of some commission firms during the economic panic of 1919.

The final internal reform enacted by the Kansas City Livestock Exchange was to set uniform consignment rates: $50 \phi /$ head for cattle and $10 \phi$ for hogs or sheep. Later, an equivalent charge of $\$ 12 /$ railcar was established for cattle. Similarly, \$6/single-deck railcar or $\$ 10 /$ double-deck railcar was assessed for hogs and sheep.

The free-trade faction within the exchange membership was furious, as were some of their larger customers; however, the members belonging to the regulator faction greatly outnumbered them and, thus, controlled the vote. Simply publishing standard consignment fees did not guarantee their enforcement. Firms belonging to the 
free trade faction initially ignored the rules governing consignment fees. Free-trader firms openly rebated commissions on large shipments of livestock. To obtain evidence of these violations, the exchange hired detectives to board stock trains moving in and out of the Southwest. When evidence was found to confirm that rebates had been offered to certain customers, the exchange board of directors levied heavy fines against the offenders. Failure to pay resulted in immediate expulsion from the exchange and the Kansas City Stockyards.

The Kansas City Livestock Exchange set an important precedent in the commercial trials of commission firms who violated the rules barring consignment fee rebates. It asserted successfully the right to regulate commission rates and to discipline violators of the rules; it also prevented the financially powerful commission firms from undermining the functions of the exchange. The only exceptions made to the consignment fee rules were for other livestock markets. It permitted commission rebates to merchants at Omaha, St. Joseph, Denver, Wichita, East St. Louis, St. Louis, Chicago,
Pueblo, Sioux City, Milwaukee, and Fort Worth on stock forwarded to Kansas City from those markets.

As Kansas City Livestock Exchange grew in prestige, it began to exert an influence on interstate commerce. It sought, for example, to get new rail mileage into Kansas City. In 1886, the year the exchange organized, ten railroads funneled traffic into Kansas City. By 1893, they numbered 16 . The number of rail cars received in 1893 was 27,483 more than in 1886 ; over half the increase came from the new railroad mileage.

The exchange also used its influence to affect national agricultural policy. In 1892, the federal government ordered cattlemen out of the Cherokee Strip grazing allotment in Indian Territory by October. The exchange directors sent a letter to Agriculture Commissioner J. M. Rusk condemning the decision. The letter explained that the strip contained from 125,000 to 170,000 cattle; expulsion of all of these cattle would glut the Kansas City market. Cattlemen in that area had no other market option inasmuch as Kansas, Colorado, and Texas forbade the movement of cattle into their grazing lands before December 1 due to fears of an outbreak of Texas fever. The exchange directors, moreover, argued that if Cherokee Strip cattlemen were forced to dump their animals on the Kansas City market, it would cause a price depression for all cattlemen in the southwest. Another mitigating factor was that the summer had been unusually dry in Indian Territory resulting in a rather sparse forage supply. This meant that the cattle there were thin and not readily marketable. The petition of the exchange met with success. The government delayed the execution of the order by two months.

The author is an assistant professor, Department of Animal Sciences, University of Missouri-Columbia, Columbia, $M O$ 65211, to whom correspondence should be addressed

\section{References}

Hazlett, O. J. 1987. Regulation in the livestock trade: the origins and operations of the Kansas City Livestock Exchange 1886-1921. Ph. D. Dissertation. Oklahoma State University, Stillwater. 